\title{
Communication as Resource: Problems of Introduction of Social Innovations in Modern Russia
}

\author{
Ekaterina Vasilieva $^{1}$, Mariya Poltavskaya ${ }^{1, *}$ and Natalya Khomutova $^{2}$ \\ ${ }^{1}$ Volgograd State University, Institute of History, International Relations and Social Technologies, 400062, University Av., 100, \\ Volgograd, Russian Federation \\ ${ }^{2}$ North-Western State Medical University named after I.I. Mechnikov, Department of Social and Human Sciences, Economics and Law, \\ 195067, Prosp. Piskarevskiy, 47, Saint-Petersburg, Russian Federation
}

\begin{abstract}
Investigation of development and implementation of social innovations in regions of Russia is an important scientific problem. A socio-economic and political situation, traditional forms of government affect the forms of business communication and their efficiency. The subjects that determine the information and communication space of innovators are business, educational institutions and the state (Triple Helix theory). We also proceed from the fact that socio-economic development of the territory (case study of Volgograd region) depends on business, government and non-profit (third) sector as the main subjects of activity. We explore the communication as a resource for the formation of innovative activity; economic, political and cultural factors of this process are also researched. The research was carried out with the support of the RFBR (The Russian Foundation for Basic Research) and the Volgograd region administration (project № 17-13-34010). Young researchers, young entrepreneurs and experts were surveyed using qualitative methods. The results of the study allowed us to gain answers to the following questions: a) what communications are required for the formation of social capital; b) how to develop and implement innovations through communication. The study has showed that the problem with communication is systemic and affects all actors.
\end{abstract}

\section{Introduction}

The theory of "Triple helix" reasoned by Etzkowitz and Leidesdorf [1] has a great influence in modern Russia. State programs are focused on building an institutional cooperation among government, business and University - the key elements of the innovation system. The innovation system and, hence, the triple helix cannot be considered outside of social space shaped not only by the institutions, but also by actors. Triple Helix theory is supplemented by the theory of cross-sector collaborations, where government, business and civil society institutions are the main institutional actors. From the institutional point of view, the non-profit sector is an implementer of the interests of citizens of the state and it is the main institution of civil society; from the functional viewpoint it acts as a mediator between the government and society. We believe that government, business, university and civil society institutions are the key institutional actors that have an influence on social innovation at the regional level.

When we analyze social and natural characteristics of the human body, we can ascertain the complexity of social space. A. Giddens, which aims at rethinking the concepts of "human being", "human activities", "social reproduction" and "social change", determines the need to study the following issues: positioning in the space- time continuum, the regionalization of interaction, practice as the sources of education of both objects and subjects, practical consciousness, everyday life (routine, constantly reproducing operations, defining reflexive (recursive) nature of social life), everyday behavior in the context of social activity, psychological mechanisms for meeting the requirements for reliability and safety.

Considering the rules and resources, A. Giddens notes that they are transformative; integration and identity are provided by social interaction that is structured by social relations; markers (gender, age, etc.) form the roles [2]. Discursive practices and discourse as a whole play an important role during interaction. Giddens insists on the study of the context of interaction (spatial-temporal boundaries, the presence of actors, awareness, monitoring of interaction process).

For example, administrative discourse has its own specificity: it is one of the ways to preserve and maintain the structure of the social institute, those hierarchical relationships that make the institute a sustainable formation. The specificity of the administrative discourse is in the inequality of its participants [3].

By accepting this, we can move on to a second important issue: communication as a resource for the formation of triple helix in the space of regions. However, we believe that it is futile to consider the communication outside of social networks, and

Corresponding authors: poltavskaya@ volsu.ru, vasilevaen@ volsu.ru, Natalya.Khomutova@szgmu.ru 
therefore, the following issue appears, which is the development of theoretical concepts of social capital. Understanding social capital as accumulated resources that are formed in social networks, experts explore social networking and communication, the efficiency of resources accumulation and the effectiveness of social capital mobilizing, etc. Great contribution to the disputation on this problem was made by Burt [4], Bourdieu [5], Woolcock [6], Granovetter [7], Coleman [8], Lin [9], Putnam [10], Portes [11], Flap [12], Fukuyama [13] and others.

Shaping the concepts of social capital and its elements, the researchers at the same time raise issues of empirical nature, solving the problem of measuring social capital. The following indicators are currently offered as helping to estimate the state of social capital: trust $[13,10,14]$; the economic growth of nations, investments and government control [15]; the efficiency of the political elites [16]; "civic community index" and "democratization index", including "electoral activity", "capacity of newspapers edition" and "the number of civil (social) organizations" [17]; J. L. Twigg's system of indicators [18] where different theoretical constructs are used: "crime rate" ("trust"), "culture" (the level of involvement in cultural events), "family" (stability and strength) and "work" (reliability of job and comfort in relationships with colleagues), communication, civic and political involvement, health, safety net and institutions of higher education.

Thus, the indicators of social capital came beyond the theory and are used to rank regions, for example, in surveys of the World Bank, World Values Survey.

In our study we rely on the ideas of R. Putnam, who first pointed out the existence of correlation between social capital and the level of economic development of the region, and on the position of J. L. Twigg - it is permissible to include in the study any possible indicators of social capital and the factors contributing to its development. To this end, it is fair to say that there is a need to consider such indicator of social capital as communication among authorities, business and university in the process of developing and introducing of social innovations.

We use the latest achievements in the field of social innovation research [19], and also appeal to the study of the roots and the history of social innovation [20].

Social innovation blurs the traditional boundaries among business, government and civil society, effectively developing new forms of services, relationships and collaboration. Creating social innovation is now carried out through new forms of cooperation $[21,22]$.

We consider the organizations of the third sector as the most perspective actors of social innovation development [23]. Initially, it was customary to refer formal organizations with employees and volunteers to the third sector. It has become clear today that it is necessary to take into account other forms of socially significant activity that can generate social innovation. These may be displaying individual initiatives, social entrepreneurship projects [24], including work of NGOs with migrants [25].
We share the view that universities can play a crucial role in inclusive development, social innovation and social entrepreneurship [26], universities can become pioneers in this field by taking initiatives in social responsibility and social innovation.

\section{Materials and methods}

The qualitative research, as well as polling of the young scientists, young businesspeople and experts (officials responsible for the development of innovation in Volgograd region) of Volgograd region, was conducted. This is one of the regions of the Russian Federation which is part of the Southern Federal district. The total area is 112.9 thousand sq. $\mathrm{km}$. The population of Volgograd region in 2017, according to the Federal State Statistics Service, is 2535202 people. Urban population is $76,6 \%$, the administrative center - the city of Volgograd, has a population of 1015586 people. Volgograd region is one of the most economically developed regions of Russia with a balanced structure of the economy.

The main issue of the research - how is communication being performed in the process of introducing of social and technology innovations in the region, - was defined in the guide of semi-structured interview. 10 interviews were conducted with young scientists, 10 interviews with experts and 20 interviews with businesspeople (2016). A study was also conducted - in-depth interviews with heads of social oriented NGOs, representatives of commercial organizations and officials. There was a total of 25 interviews $(\mathrm{N}=25)$; the selection criteria for experts are the existence of experience of intersectoral interaction (2017). The processing of research results was carried out in the QDA Miner program, as well as the procedure of axial coding was conducted.

\section{Results and discussion}

Assessment of possibilities for development of "triple helix of innovation" in the Russian regions was carried out through searching for communications between the potential and actual participants in the space of triple helix.

The interaction system "Government-BusinessUniversity" has been tested in many areas of Russia and CIS countries (Kazakhstan, Belarus). Using the case of Volgograd region as an example, we set a goal - to reveal the nature of communication between government, business and universities in the region. However, interviews with government officials, entrepreneurs and young scientists of Volgograd region show the limitations of its development. Let us give just a few examples from interviews with businesspeople:

"Interviewer: Tell us the technology of implementing innovative products in your own business.

Respondent: If there is a demand in the market, it can be implemented". 
"Interviewer: What, for example, can make the government to reduce risks from the introduction of innovative products?

Respondent: If you think about it, the best help is [...] not to interfere..."

Here is the example from an interview with a young scientist:

"Interviewer: Is it possible to support or implement through the business structure innovations developed in your University?

Respondent: Only if there is informal networking [...] it is good when our graduate students are getting jobs there, so then connections improve, the confidence in our projects grows..."

The example from an interview with a young scientist:

"Interviewer: What should or should not do the administration?

Respondent: we need the labs to conduct the necessary experiments, we need the labs... we need the equipment, but sometimes it is not available or we do not have formal and informal connections to use it..."

An interview with an official:

Interviewer: "How do you build communication for implementation of innovative products?

Respondent: It goes hard. We have interesting projects in our view, but this does not mean that business will be interested in them".

Thus, the adverse situation is showing up. We have enough human capital for the development of innovative activity in the Russian regions, but social capital is not sufficient, and tools for implementation are limited. Due to a number of reasons, there are no established conditions for the institutionalization of new practices of communication in business and science. It was often heard in interviews in relation to different aspects: "the interaction has not been established, they are not informed, etc.".

The model of the "triple helix", with the support of which it is possible to form a social partnership between the state, business and university was supplemented by a model of intersectional interaction, in which there are three actors - the state, business and civil society. Finally, we can talk about four key institutional actors in the region on which the development of social and technological innovation depends. These actors are Government - Business - University - civil society institutions. The creation of "triple helix" is due to the need of integrating business and universities, inclusion of science into the sphere of the relations of production, withdrawal of research results to the market. In turn, the problem of organizing effective forms of interaction between institutional entities and building communication networks becomes more urgent.

Communication is a weak point in the interaction among government, business and civil society institutions (primarily non-profit organizations).

Here are examples from interviews with heads of socially oriented NGOs:

"Interviewer: Tell us how the interaction with the authorities and officials is built.
Respondent: For me, every meeting with a representative of the authorities is [...] disappointment, shattering illusions; we will not come to a common denominator anyway".

"When you start to work and find solutions, to do something and then you run into an administrative machine. When you, in order to do something, need to go through 250 authorities, wait a few years. Here you need to write paper, wait for the answer. This is the whole routine called by one word - tiresomeness".

Effective communication, the ability to build a dialogue between partners during the interaction is a very important component of the implementation of social innovation.

Respondent: "What are the main difficulties you encounter when interacting with government officials."

Interviewer: "All this comes to rest upon a misunderstanding of the officials to the problems of our organization, our community, the incompetence of officials, when we say, for example, about the needs of the disabled. To establish communication, you need to invite NGOs to discuss projects. Before you start something in the masses - you need to invite public organizations for discussion".

The heads of the socially oriented NGO also noted the problem of non-compliance, especially during the electoral period:

"The elections will be finished, the authority will change, and they will say: "We hear you for the first time ever". So all the agreements vanish like this"; "Today you are at the certain government, you are liked, all is well and everyone is happy, but the other official will come and you therefore will be unwanted".

The interaction of actors in the triple helix model, as well as in the framework of the model which takes into account four key institutional actors in the region (government, business, universities and civil society institutions), can create an environment for partnership initiatives, create a platform for dialogue, which will contribute to the development of social and technological innovations.

Our research has shown that the problem with communication is systemic and affects all institutional actors. Consequently, we can speak about the strategy of economic growth through the development of innovation only as of the process of developing communication.

\section{Conclusion and recommendation}

The analysis of strategic behavior of the members of all expert groups has shown that in focus there are ways by which actors use structurally properties in the process of establishing of social relationships, and informal tools are practically not used. According to E. Giddens, the actors are aware of why they act one way or another, but they do not think about it until they are asked the direct questions. We suggest enhancing the analysis with theoretical objectives of L. Boltanski and L. Thevenot [27]. Critique and grounding of justice can fill some theoretical gaps, namely, admit that the actors have their own interests that do not interfere with building social 
identities (Giddens' concept), not developing (except for critical points) into continuous fighting (that is a weak position of conflict management). It is possible to explain the conditions of the search of justice in different worlds (the world of inspiration, home world, civil peace, the world of point of views, the world of market, industrial world) by the search of invalence which shows what is in common between actors. The authors of the conception call the search for invalence "the excuse mode" far from diminishing the role of domination and enforcement (and even fraud).

The main conclusion is that formal communication is extremely rationalized and bureaucratized; and informal communications, on the one hand, carry the risk of misuse of official position and, on the other hand, can facilitate the introduction of social innovations.

The non-profit sector is a source of social innovation. Many educational, social and information technologies were implemented for the first time by non-profit organizations. For the full development of the region, the state as an institutional actor should channel significant investments in the third sector (in the development of its initiative and creativity), while delegating authority and responsibility for the effectiveness of these investments to civil society institutions (NGOs).

In its turn, the state can receive additional resources from non-profit organizations for its development: the possibility of disseminating information to representatives of various social groups, assistance in solving the problems of citizens, independent judgments, expert assessments of situations, and recommendations. Given that non-profit organizations work at a level much closer to the population and are directly related to civic interests and initiatives, they can help public authorities to work with citizens' appeals, set up citizens' forums.

So we can talk about an attempt to create an additional institutional subsystem by the state as an institutional actor - building network social problems solutions technology through the use of social initiatives of non-profit organizations and business structures. As a result, the state attracts alternative (non-state) social structures to solve social problems, develop and implement social and technological innovations.

The new social role of subjects of institutional activity creates other values. For example, the institute of higher education stimulates scientific research and focuses on obtaining a new result. In the search for effective technologies of congruence of interests of society and the state, the practice of interaction of researchers with active representatives of public policy at the regional and federal levels is applied [28].

Communications in the triple helix model remove many institutional barriers for the dissemination of knowledge, create conditions for social and technological innovations.

Factors of formation of effective communication are interest of subjects of activity, intersectional partnership, observance of the principles of equality and justice.

As a result of inefficient communications, we can talk about "double" rather than "triple helices" of relations. Due to the dominance of vertical relations between the state and other participants of intersectoral cooperation, we cannot talk about a full-fledged partnership in Volgograd region. The setting of communications in the framework of the "double helix" (state - business, state - University, business - university) is currently fulfilled. This type of communication is the basis, but it should be considered that there are four key institutional actors in the region that influence the development and implementation of social and technological innovations. The existence of wellestablished communications between them is an important resource and directly affects the success of social and technological innovations in the region.

The study was carried out on the basis of Volgograd State University within the framework of research project № 17-1334010 "Resource potential of non-profit organizations in the social entrepreneurship" with the financial support of the Russian Foundation for Basic Research (RFBR) and the Volgograd region administration.

\section{References}

1. H. Etzkowitz, L. Leydesdorff, EASST Review 14, 14-19 (1995)

2. A. Giddens, The Constitution of Society. Outline of the Theory of Structuration (Polity Press, Cambridge, UK, 1984)

3. O. A. Evtushenko, Science Journal of VolSU. Linguistics 16 (3), 122 (2017)

4. R. S. Burt, AJS 110 (2), 349-399 (2004)

5. P. Bourdieu, Forms of capital In: J.C. Richards (ed.). Handbook of Theory and Research for the Sociology of Education (Greenwood Press, NY, 1983)

6. M. Woolcock, Theory Soc. 27, 151-208 (1998)

7. M. Granovetter, AJS 91, 481-510 (1985)

8. J. C. Coleman, AJS 94, 95-120 (1988)

9. N. Lin, Social Capital: A Theory of Social: Structure and Action (Cambridge University Press, NY, 2001)

10. R. D. Putnam, Making Democracy Work: Civic Traditions in Modern Italy (Princeton University Press, Princeton, NJ, 1993)

11. A. Portes, Annual Review of Sociology 22, 1-24 (1998)

12. H. D. Flap, No Man is an Island: The Research Program of a Social Capital Theory (World Congress of Sociology, Bielefeld, 1994)

13. F. Fukuyama, Foreign Affairs 74 (5), 89-103 (1995)

14. Ch. Bjornskov, European Journal of Political Economy 22 (1), 22-40 (2006)

15. S. Knack, Ph. Keefer, Quarterly Journal of Economics 112 (4), 1251-1288 (1997)

16. T. Cusak, Eur. J. Political Res. 35 (1), 1-34 (1999) 
17. C. Marsh, Demokratizatsiya: The Journal of PostSoviet Democratisation 10 (1), 19-36 (2002)

18. J. L. Twigg, Social Capital in Russia's Regions. In: Judith L. Twigg, K. Schecter. (eds.) Social Capital and Social Cohesion in Post Soviet Russia (Taylor \& Francis, M. E. Sharpe, 2003)

19. W. Rammert, A. Windeler, H. Knoblauch, M. Hutter, Innovation Society Today: Perspectives, Fields, and Cases (Springer Fachmedien Wiesbaden, Wiesbaden, 2018)

20. K. McGowan, F. Westley. At the Root of Change: The History of Social Innovation. In: New Frontiers in Social Innovation Research (Palgrave Macmillan, London, 2015)

21. E. Sørensen, J. Torfing, Enhancing Public Innovation through Collaboration, Leadership and New Public Governance, p. 145-169. In: A. Nicholls, J. Simon, M. Gabriel (eds.) New Frontiers in Social Innovation Research (Palgrave Macmillan, London, 2015)

22. A. Evers, B. Ewert, Social Innovation for Social Cohesion, p.107-127. In: A. Nicholls, J. Simon, M. Gabriel (eds.) New Frontiers in Social Innovation Research (Palgrave Macmillan, London, 2015)

23. I. I. Krasnopolskaya, I. V. Mersianova, Public Administration Issues 2, 29-52 (2015)

24. E. G. Vasilyeva, M. B. Poltavskaya, Logos et Praxis 16 (4), 31-40 (2017)

25. E. Vasilieva, E. Danilova, S. Tokareva, Theoretical and Empirical Researches in Urban Management 12 (1), 5-20 (2017)

26. L. Gokhberg, V. Poliakova, S. Zaichenko, A. Suslov, Universities as Actors of Inclusive Development in Russia, p.283-309. In: C. Brundenius, B. Göransson, de M. Carvalho \& J. Manoel (eds.) Universities, Inclusive Development and Social Innovation: An International Perspective, (Springer, Cham Switzerland, 2017)

27. Luc Boltanski, L. Thevenot, On Justification: Economies of Worth (Princeton University Press, Princeton, NJ, 2006)

28. S. A. Pankratov, E. G. Kirsanova, E. N. Seyfieva, Science Journal of VolSU. History. Area Studies. International Relations 23 (1), 189 (2018)

\footnotetext{
* Corresponding authors: poltavskaya@volsu.ru, vasilevaen@ volsu.ru, Natalya.Khomutova@szgmu.ru
} 